\title{
ГРАМАТИЧНІ ЗАСОБИ ВИРАЖЕННЯ ОЦІНКИ В СУЧАСНІЙ УКРАЇНСЬКІЙ МОВІ
}

\author{
(Халіман О. В. Граматика оцінки: морфологічні категорії укра- \\ їнської мови / переднє слово, наук. ред. проф. Т. Космеди. Харків: \\ Майдан, 2019. 458 с.)

\begin{abstract}
...категорія оцінки пронизує всю мовну тканину без винятку, зокрема й граматичний лад.

Це виразна й активна реалізація «людського чинника»
\end{abstract}

(Тетяна Космеда)

Рецензоване студіювання Оксани Володимирівни Халіман присвячене комплексному аналізу граматичних одиниць як засобів вираження аксіологічних смислів. Попри наявність вагомих надбань у рамках вітчизняної та закордонної аксіологічної лінгвістики (праці М. Алефіренка, Н. Арутюнової, О. Бабаєвої, О. Вольф, Г. Гібатової, Т. Космеди, Т. Маркелової, Г. Приходько, В. Телії, 3. Фоміної та ін.) авторка знаходить актуальні аспекти для подальших наукових пошуків й акцентує увагу на описі механізмів породження оцінки за участю граматичних засобів (морфологічних і синтаксичних), що уможливить об'єднання граматичних значень, схарактеризованих з огляду на їхню актуалізацію в мовленнєвому процесі, на грунті їхньої прагматичної значущості з урахуванням відповідної функційної спеціалізації (оцінної функції).

Вибір граматики оцінки (арсенал граматичних засобів вираження оцінних значень з урахуванням їніх прагматичних характеристик) об'єктом розвідки, а морфології оцінки (морфологічні засоби вираження аксіологічних смислів в українському мовному просторі) - предметом унеобхіднює адекватне застосування здобутків морфології, граматичної стилістики, прагмалінгвістики, лінгвоаксіології, комунікативної лінгвістики, гендерної лінгвістики, психолінгвістики, ономастики, лексикографії.

Дослідження постає важливою спробою: 1) окреслити сутність оцінки як багатоаспектної категорії в сучасній науковій парадигмі; 2) висвітлити основні етапи становлення й розвитку граматики оцінки; 3) схарактеризувати лінгвофілософське підгрунтя морфології оцінки; 4) обгрунтувати методологічні засади породження оцінних 
відтінків значення на основі актуалізації морфологічних засобів; 5) репрезентувати метамову дослідження; 6) виокремити морфологічні засоби моделювання тропів як продуктивних репрезентантів оцінних значень; 7) аспектуально з'ясувати аксіологічну специфіку реалізації граматичних ігрем у мовленнєвих жанрах; 8) описати механізми моделювання оцінних морфологічних (іменних і дієслівних) ігрем, типові моделі вияву оцінного компонента на основі актуалізації граматичних значень; 9) визначити ступінь частотності їхнього поширення в сучасній мовленнєвій практиці українців.

Структура роботи може бути повністю схвалена як така, що логічно підпорядковується поставленій меті, композиція розділів відповідає послідовності конкретних завдань, що вирішуються. Виклад матеріалу визначуваний логічністю та послідовністю.

Перший розділ «Граматика оцінки. Методологія дослідження та його термінологічний інструментарій: проекція на морфологічні ресурси мови» містить грунтовний аналітичний огляд стану дослідження категорії оцінки в сучасній науковій парадигмі та позиціонує граматику оцінки як самостійний науковий напрям. Авторка окреслює витоки, становлення й основні етапи розвитку граматики оцінки; засади вивчення граматичних засобів вираження аксіологічних смислів; лінгвофілософське підгрунтя граматики оцінки. Значну увагу приділено методологічним засадам породження оцінних відтінків значення з послідовним висвітленням таких питань: морфологічні одиниці у функції засобів моделювання значення оцінки, термінологічне поле граматики оцінки, морфологічні засоби моделювання тропів як продуктивні репрезентанти оцінних значень, аксіологічні аспекти реалізації граматичних ігрем у мовленнєвих жанрах.

У другому розділі «Граматичні категорії іменних частин мови у бокусі граматики оцінки» цілком передбачувано та логічно схарактеризовано граматичні категорії: а) роду з визначенням специфіки граматичних значень чоловічого, жіночого й середнього родів як основ механізмів породження оцінки. Значну увагу приділено реалізації гендерно маркованих ігрем у системі частин мови; б) числа з актуалізацією граматичних значень множини (множина гіперболічна, узагальнювальна множинність, синтаксичні фразеологізми за участю множинних числових форм, реалізація оцінного потенціалу граматичного значення множини в системі частин мови, лексико-граматичний 
оксиморон (креативні множинні форми сингулятивів, функціювання онімів), множина пошанна, удавана пошанність тощо) й однини (однина експресивно-оцінна, лексико-граматичний оксиморон (моделювання форм однини плюративів), однина пошанна, однина агресивна); г) відмінка з актуалізацією граматичних значень відмінка в системі частин мови тощо.

Третій розділ «Дієслівні граматичні категорії у бокусі граматики оцінки» також прогнозовано презентує погляди авторки на граматичні категорії: а) виду (контекстуальне протиставлення видових форм, видові протиставлення імперативних форм, оказіональні видові утворення); б) часу з чітким окресленням транспозиційних можливостей грамеми минулого часу (моделі “Боявся я іï, “Ну, приїхала я туди, а потім що?”, “А потім йому швидко кубики почепили..., “Ми попали!”, “Сіли!”), особливостей функціювання теперішнього емоційної актуалізації, вторинних (оцінних) значень форм майбутнього часу (моделі “Буде він мені розповідати!”, “Відпочинеш тут!”, “Як вискочить!”, “Сидітимеш удома!”); в) особи; г) способу з моделюванням оцінки як наслідку транспонованого вживання імперативних форм (наприклад, “драматичний імператив” (модель “А хтось і ляпни / візьми й ляпни / візьми та й ляпни...”), імператив емоційної актуалізації дії (моделі “Інші гуляють, а я працюй!”, “Грошей їй дай...”), моделі “Отак і роби добро!” та “Поговори мені тут!” тощо); г) характеристика зв’язку активного / пасивного стану з перехідністю / неперехідністю, зворотністю й безособовістю; д) інфінітива (моделі “А він кричати!”, “Сидіти!”, “А прибрати?”).

Висновки $є$ достатньо аргументованими, мають важливий теоретичний і прикладний характер для сучасного українського мовознавства.

Вагомим здобутком розвідки постають Додатки, що системно репрезентують частотність поширення оцінних граматичних ігрем.

Позитивно оцінюючи обгрунтованість наукових положень роботи, уважаємо за доцільне висловити авторці кілька зауважень і побажань:

1. У рецензованій роботі чітко визначено межі та системні зв'язки термінологічного поля граматики оцінки (пп. 1.3.2. Граматика оцінки: термінологічне поле). Водночас зауважимо, що специфіка матеріалу вимагає укладання термінологічного словника граматики оцінки як окремого напряму лінгвоаксіології. Це міркування мотивоване також тезою авторки про те, що тлумачення деяких термінів на сьогодні 
ще не усталені й потребують уточнення (напр., «граматикалізація оцінки»), а дефініції окремих лише формуються (напр., «граматична прецедентність», «лексико-граматичний оксиморон», «однина агресивна» та ін.).

2. Проведений аналіз уможливив опис механізмів моделювання оцінки, грунтованих на переосмисленні граматичних значень роду, числа й відмінка (другий розділ) і пов'язаних із уживанням граматичних значень виду, часу, особи, способу, стану (третій розділ). Виділені моделі репрезентують підтипи, різновиди вживань, що вирізняються різною частотністю використання та послідовністю вираження в сучасній комунікації. На нашу думку, цікаво було 6 простежити та наочно представити кореляцію оцінних ігрем з оцінною шкалою.

Утім зазначені міркування мають дорадчий характер і не знижують значення рецензованої праці. Репрезентативність досліджуваного корпусу, широке охоплення теоретичних джерел, комплексне використання методів $€$ підгрунтям для достовірності й об’єктивності одержаних результатів.

Закцентуємо увагу на тому, що авторка окреслює перспективу дослідження та вбачає ії в доповненні лінгвістичної, зокрема й навчальної літератури описами нових функцій мовних одиниць, коментарями щодо специфіки нових породжуваних значень, моделюванні нових прагматичних норм, кодифікації відповідних тенденцій у граматиках української мови, фіксації й поясненні нових семантичних відтінків у лексикографічних джерелах тощо. Погоджуємося з Оксаною Володимирівною в тому, що дослідницька перспектива досить широка, а найголовніше - необхідно продовжити розробку граматики оцінки в проекції на синтаксичні ресурси мови.

Краснобаєва-Чорна Жанна Володимирівна - доктор філологічних наук, доцент, професор кафедри загального та прикладного мовознавства і слов'янської філології, Донецький національний університет імені Василя Стуса; вул. 600-річчя, 21, м. Вінниця, 21021, Україна.

Tel.: +38-066-399-37-79

E-mail: zh.krasnobaieva@gmail.com

https://orcid.org/0000-0001-7819-8094

Krasnobaieva-Chorna Zhanna - Doctor of Philology, Associate Professor, Department of General and Applied Linguistics and Slavic Philology, Vasyl Stus Donetsk National University; 600-richchia Str. 21, Vinnytsia, 21021, Ukraine.

Надійшла до редакції 02 лютого 2020 року 